\title{
Grand Strategy Obama: Pivot to Asia
}

\author{
Agastya Wardhana \\ Pusat Studi ASEAN, Universitas Airlangga
}

\begin{abstract}
ABSTRAK
Kebijakan luar negeri Amerika Serikat memiliki dampak yang besar dalam konstelasi internasional. Oleh karenaitu,pemahaman akan kebijakan luarnegeri pada setiap era akan membantu kita dalam memahami tujuan dan kepentingan yang ingin dicapai oleh Amerika Serikat. Dalam setiap implementasinya, kebijakan luar negeri Amerika Serikat dapat dianalisis menggunakan kajian Grand Strategy, siapapun presiden yang sedang menjabat pada masa itu. Tulisan ini bertujuan untuk menganalisis kebijakan luar negeri Obama pada periode kedua. Menggunakan kombinasi Grand Strategy milik Cristopher Lyne serta Possen \& Ross, penulis berargumen bahwa kebijakan luar negeri Obama dilaksanakan berdasar corak selective engagement. Selective engagement ini ditunjukkan melalui adanya upaya pencapaian kepentingan nasional dengan merespon terhadap ancaman yang ada. Dalam konteks ini kepentingan yang ingin dicapai oleh Obama adalah restorasi kepemimpinan Amerika Serikat oleh karena itu ancaman paling nyata yang hadir adalah naiknya Cina maka pemerintahan Obama lantas mengeluakan kebijakan Pivot to Asia. Hal ini dikarenakan Cina memiliki kekuatan cukup besar di kawasan Asia sehingga Amerika Serikat sehingga Amerika Serikat memilih Asia sebagai target kebijakannya.
\end{abstract}

Kata-kata kunci: Grand Strategy, Amerika Serikat, Obama, Selective Engagement, Pivot to Asia.

US foreign policy have great impact on the conduct of international relations. Therefore the more we understand the nature of it, the better we will comprehend the interest and behavior of United States. In practice, the conduct of US foreign policy can be analysed using Grand Strategy approach, whoever the president was in office at that time. This paper therefore aimed to analyse Obama foreign policy in his second period using the given approach. By using a combined approach of Christopher Layne and Possen \& Ross Grand Strategy theory, the author argue that Obama foreign policy conduct was leaning toward selective engagement pattern. This was signified by the national interest and response of threat that happened during Obama reign. In this context the Obama aimed to restore US leadership therefore the threat to that aim was the rise of China in US sphere of influence and the means to achieved it was by Pivot to Asia policy.

Keywords: Grand Strategy, United States of America, Obama, Selective Engagemenet, Pivot to Asia 
Presiden Amerika Serikat merupakan salah satu orang paling berpengaruh di dunia dan oleh sebab itu segala kebijakan, utamanya kebijakan luar negeri yang dilaksanakan dapat memberikan implikasi pada dinamika internasional. Dalam menjalankan kebijakan luar negerinya, Amerika Serikat memiliki corak khas melalui sebuah strategi utama yang dianut oleh setiap presidennya. Konsep ini kemudian di kenal sebagai Grand Strategy (Posen \& Ross 1996; Layne 1998).

Grand Strategy merupakan sebuah kebijakan atau sekumpulan kebijakan yang merupakan hasil dari preferensi dan formulasi tujuan yang dikeluarkan oleh pengambil kebijakan dalam hal ini presiden Amerika Serikat. Dalam dinamika politik luar negeri Amerika Serikat, kapabilitas untuk menjalankan kebijakan luar negeri diatur dalam Pasal II konstitusi yang memberikan kuasa penuh pada Presiden untuk memimpin dan memformulasikan kebijakan yang tepat bagi negara (US Constitution Article II). Namun, dalam prakteknya seringkali terdapat perbedaan Grand Strategy yang diterapkan oleh tiap presiden dalam tiap era kepemimpinannya. Hal ini dikarenakaan oleh adanya pengaruh dinamika domestik, faktor individual hingga dinamika sistemik (Wittkopf \& Jones 2008).

Dalam aplikasinya, Grand Strategy Amerika Serikat menjadi menarik untuk dipahami, utamanya oleh negara-negara lain di dunia untuk dapat memahami dan memprediksi arah kebijakan luar negeri Amerika Serikat. Hal ini dapat menjadi peluang bagi kerjasama atau dapat menjadi peringatan bagi potensi ancaman di masa yang akan datang. Dalam sejarahnya Grand Strategy mulai diterapkan sejak era Perang Dunia II hingga sekarang, namun perubuahan signifikan terjadi paska era 2000an ketika tragedi 9/11 mengubah trajektori kebijakan luar negeri Amerika Serikat (Layne 2006). Presiden Bush pada waktu itu mengeluarkan dotkrin unilateralisme yang menggarisbawahi pentingnya strategi War on Terror dalam kebijakan luar negeri Amerika Serikat (Gardner 2005).

Unilateralisme Amerika Serikat muncul sebagai respon terhadap ancaman utama di era Bush yaitu kehadiran terorisme dan ancaman jatuhnya senjata pemusnah masal ke tangan teroris (Hirsh 2002). Donald Rumsfeld menteri pertahanan Amerika Serikat dalam kaitan dengan hal ini menyatakan:

"There are things we know that we know. There are known unknowns. That is to say, there are things that we know we don't know. But there are also unknown unknowns. There 
are things we don't know we don't know. ... Each year, we discover a few more of those unknown unknown" (Rumsfeld 2002)

Dengan kata lain, di seluruh dunia dapat saja muncul kelompok teroris yang tidak diketahui yang memiliki senjata pemusnah masal yang dapat menyerang Amerika Serikat kapanpun dan di manapun. Oleh karena itu, pemerintahan Amerika Serikat di bawah Bush menggunakan strategi preventif dan preemtif dalam merespon terhadap ancaman yang ada ${ }^{1}$. Seringkali aksi-aksi tersebut mengabaikan dan mengecilkan peran institusi internasional serta aliansi akibat adanya kepentingan dalam merespon terhadap ancaman(Leffler 2004). Doktrin ini membuat Amerika Serikat menegaskan kekuatannya sebagai negara adidaya dengan mengerahkan segala daya dan upayanya untuk memerangi terorisme di seluruh dunia.

Sesudah Presiden Bush, penerusnya yaitu Barrack Obama menjalankan Grand Strategy yang jauh berbeda dengan pendahulunya. Obama menekankan pada opsi engagement. Hal ini digarisbawahi Obama dikarenakan ia menganggap aksi-aksi unilateral tidak dapat dijustifikasi namun terorisme dan keunggulan Amerika Serikat tetap harus dijaga utamanya melalui kerangka aturan internasional dan kerjasama internasional(Obama 2009; Rowland 2008; Drezner 2011). Dalam prakteknya, Obama juga mendorong penggunaan Soft Power sebagai instrumen utama kebijakan luar negeri pada periode pertama pemerintahannya (Hayden, 2012). Dalam tulisannya mengenai kebijakan luar negeri pada 2007 ia menyatakan bahwa "the security and well-being of each and every American
depend on the security and well-being of those who live
beyond our borders. The mission of the United States is to
provide global leadership grounded in the understanding
that the world shares a common security and a common
humanity" (Obama 2007)

\footnotetext{
1 Untuk pemahaman lebih lanjut mengenai aksi preventif dan preemtif Amerika pada era Bush dapat dilihat pada Fawn, Rick, and Raymond A. Hinnebusch, eds. The Iraq War: Causes and Consequences. Boulder: Lynne Rienner Publishers, 2006 atau Hinnebusch, Raymond. "The US invasion of Iraq: Explanations and implications." Critique: Critical Middle Eastern Studies 16.3 (2007): 209-228.
} 
Hal ini kemudian diwujudkan melalui Grand Strategy yang berfokus pada restorasi kekuatan Amerika Serikat dan mempererat kerjasama internasional melalui multilateralisme. Pada periode pertama kepemimpinannya, setidaknya terdapat beberapa landmark kebijakan luar negeri yang dicapai seperti menjadi mediator dalam konflik IsraelPalestina, menginisiasi pembicaraan mengenai pengembangan nuklir Iran, serta mendorong pembentukan pemerintahan di Afghanistan (Brzezinski 2010).

Ide-ide engagement dan kerjasama internasional ini menjadi fokus Grand Strategy yang lantas berubah pada periode kedua Presiden Obama. Perubahan ini terjadi akibat munculnya kondisi sistemik yang berbeda sehingga Obama harus mengubah dan menyesuaikan Grand Strategy yang dijalankan oleh Amerika Serikat. Tulisan ini lantas menggarisbawahi periode kedua Barrack Obama dengan tujuan untuk memetakan dan menjelaskan Grand Strategy yang dijalankan. Dengan menggunakan teori Grand Strategy Cristopher Layne serta Posen \& Ross, penulis berargumen bahwa Pivot to Asia merupakan corak Grand Strategy pada periode kedua pemerintahan Obama. Hal ini dikarenakan Obama mengubah paradigma dari engagement menjadi selective engagement. Perubahan paradigma ini ditunjukkan oleh tiga hal yaitu adanya perubahan kepentingan nasional, adanya ancaman terhadap kepentingan nasional serta adanya alokasi sumber daya untuk mempertahankan kepentingan nasional tersebut.

\section{Pola Grand Strategy Amerika Serikat}

Dalam kajian mengenai Grand Strategy Amerika Serikat terdapat beberapa penulis yang memberikan kontribusi diantaranya yang paling terkenal adalah Christopher Layne. Layne mengambil kesimpulan dari beberapa penstudi Grand Strategy yang awalnya merupakan kajian militer dan menerapkannya dalam kajian mengenai kebijakan luar negeri ${ }^{2}$. Ia menyatakan bahwa dalam melakukan analisis terhadap Grand Strategy ada setidaknya tiga indikator yang harus dipetakan yaitu

2 Untuk mengetahui lebih lanjut mengenai Grand Strategy Amerika secara umum lihat Robert J. Art, "A Defensible Defense: America's Grand Strategy After the Cold War," Znternational Security, Vol. 15, No. 4 (Spring 1991), pp. 5-53; Samuel P. Huntington, "America's Changing Strategic Interests," Survival, Vol. 33, No. 4 (January/February 1991), pp. 3-17; Joseph Joffe, "'Bismarck' or 'Britain'? Toward an American Grand Strategy after Bipolarity," Znternational Security, Vol. 19, No. 4 (Spring 1995), pp. 94-117 
prioritas kepentingan nasional, ancaman terhadap kepentingan nasional serta alokasi sumber daya untuk melawan ancaman terhadap kepentingan nasional tersebut. Ketiga indikator ini merupakan faktor penting yang berkontribusi terhadap analisis Grand Strategy.

Lebih lanjut Layne menyatakan ada setidaknya dua macam Grand Strategy Amerika Serikat yaitu Preponderance dan Offshore-Balancing(Layne 1998; 2007) hal ini sedikit berbeda dengan Possen dan Ross yan menyatakan bahwa ada setidaknya empat macam varian Grand Strategy Amerika Serikat yaitu Neo-isolasionisme, Selective Engagement, Cooperative Security dan Primacy(Posen \& Ross : 1997).

Layne mengelompokkan Grand Strategy berdasarkan kapabilitas dan tanggung jawab kebijakan luar negeri Amerika Serikat di dunia. Menurutnya selama ini Amerika Serikat menjalankan strategi preponderance dengan menunjukkan kapabilitasnya sebagai hegemoni di dunia.Strategi ini menekankan pada penggunaan kekuatan dan pengaruh untuk menjaga dominasi Amerika Serikat di seluruh dunia.Strategi ini menurutnya berhasil dilakukan paling tidak hingga perang Dingin. Hal ini dikarenakan dengan menegaskan status sebagai hegemoni Amerika Serikat akan mengarah pada bahaya over extension dan mendorong adanya kekuatan-kekuatan lain untuk menantang hegemoninya (Layne 1997). Oleh karena itu Layne menyatakan ada strategi alternatif lain yang bisa digunakan Amerika Serikat yaitu offshore balancing yang berangkat dari logika balance of power. Dalam strategi ini, Amerika Serikat tidak harus menjadi hegemoni di dunia namun berfokus pada upaya-upaya untuk melindungi integritas teritorial serta mencegah lahirnya hegemoni pada ruang lingkup pengaruhnya saja. Lebih lanjut strategi ini juga bertujuan mengurangi keterlibatan Amerika Serikat dalam bantuan militer pada sekutu-sekutunya seperti Jepang, Korea Selatan hingga kawasan Eropa(Layne 1997).

Berbeda dengan Layne Possen dan Ross memiliki klasifikasi yang sedikit berbeda dalam konteks Grand Strategy. Menurutnya terdapat setidaknya empat pola Grand Straategy Amerika Serikat yaitu Neo isolasionisme, selective engagement, cooperative security dan primacy. Neoisolasionisme berangkat dari paradigma defensif realis yang bertujuan untuk memfokuskan sumber daya dan kapabilitas untuk mengusahakan pertahanan diri dan survivalitas Amerika Serikat dengan menarik diri dari dunia Internasional. Selective engagement berangkat dari asumsi yang sama dengan strategi offshore balancing Layne yaitu logika 
balance of power. Cooperative security lahir dari logika liberalisme dan multilateralisme. Yang terakhir, Primacy berkaitan dengan strategi hegemoni atau sejalan dengan argumen Layne mengenai preponderance.

\begin{tabular}{|c|c|c|c|c|}
\hline & Neo-holationism & $\begin{array}{c}\text { Selective } \\
\text { Engagement }\end{array}$ & Cooperative Security & Primacy \\
\hline Analytical Anchor & $\begin{array}{l}\text { Minimal, defensive } \\
\text { realism }\end{array}$ & $\begin{array}{l}\text { Traditional balance } \\
\text { of power realism }\end{array}$ & Liberalism & $\begin{array}{l}\text { Maximal realism/ } \\
\text { unilateralism }\end{array}$ \\
\hline $\begin{array}{l}\text { Major Problem of } \\
\text { Inti Poltics }\end{array}$ & $\begin{array}{l}\text { Avoiding entangle- } \\
\text { ment in the affairs } \\
\text { of others }\end{array}$ & $\begin{array}{l}\text { Peace among the } \\
\text { major powers }\end{array}$ & $\begin{array}{l}\text { The indivisibility of } \\
\text { peace }\end{array}$ & $\begin{array}{l}\text { The rise of a peer } \\
\text { competitor }\end{array}$ \\
\hline $\begin{array}{l}\text { Preferred World } \\
\text { Order }\end{array}$ & $\begin{array}{l}\text { Distant balance of } \\
\text { power }\end{array}$ & Balance of power & Interdependence & Hegemonic \\
\hline Nuclear Dynamics & Supports status quo & Supports status quo & Supports aggression & Supports aggression \\
\hline $\begin{array}{l}\text { Conception of } \\
\text { National Interests }\end{array}$ & Narrow & Restricted & Transnational & Broad \\
\hline Regional Priorities & North America & Industrial Eurasia & Global & $\begin{array}{l}\text { Industrial Eurasia } 8 \\
\text { the home of any } \\
\text { potential peer } \\
\text { competitor }\end{array}$ \\
\hline Nuclear Proliferation & Not our problem & $\begin{array}{l}\text { Discriminate } \\
\text { prevention }\end{array}$ & $\begin{array}{l}\text { Incliscriminate } \\
\text { prevention }\end{array}$ & $\begin{array}{l}\text { Indiscriminate } \\
\text { prevention }\end{array}$ \\
\hline NATO & Withdraw & Maintain & Transform $\&$ expand & Expand \\
\hline Regional Conflict & Abstain & $\begin{array}{l}\text { Contain; discriminate } \\
\text { intervention }\end{array}$ & Intervene & $\begin{array}{l}\text { Contain; discriminate } \\
\text { intervention }\end{array}$ \\
\hline Ethnie Conflict & Abstain & Contain & $\begin{array}{l}\text { Nearly incliscriminate } \\
\text { intervention }\end{array}$ & Contain \\
\hline $\begin{array}{l}\text { Humanitarian } \\
\text { Intervention }\end{array}$ & Abstain & $\begin{array}{l}\text { Discriminate } \\
\text { intervention }\end{array}$ & $\begin{array}{l}\text { Nearly indiscriminate } \\
\text { intervention }\end{array}$ & $\begin{array}{l}\text { Discriminate } \\
\text { intervention }\end{array}$ \\
\hline Use of Force & Sel-defense & Discriminate & Frequent & At will \\
\hline Force Posture & $\begin{array}{l}\text { Minimal set-defense } \\
\text { force }\end{array}$ & Two-MRC force & $\begin{array}{l}\text { Reconnaissance } \\
\text { strike complex for } \\
\text { mutilateral action }\end{array}$ & $\begin{array}{l}\text { A two-power- } \\
\text { standard force }\end{array}$ \\
\hline
\end{tabular}

(sumber: Possen \& Ross 1997)

Dari argumentasi baik Layne maupun Possen \& Ross, kepemimpinan Barrack Obama lebih menunjukkan corak selective engagement dikarenakan terdapat fokus untuk menjaga status quo dan mengembalikan kepercayaan terhadap Amerika Serikat di dunia. Hal ini dikarenakan terdapat ancaman terhadap kepentingan tersebut dengan munculnya kekuatan yang dapat mengganggu upaya menjaga status quo tersebut melalui naiknya Cina. Yang paling terlihat sebagai corak dari selective engagement dalam pemerintahan Obama adalah upaya untuk melakukan penangkalan dan pencegahan terhadap potensi ancaman tersebut melalui alokasi sumber daya yang lebih di kawasan Asia melalui strategi Pivot to Asia.

\section{Kepentingan dan Potensi Ancaman Terhadap Amerika Serikat}

Indikator pertama mengenai Grand Strategy yang harus dilihat adalah identifikasi kepentingan nasional. Amerika Serikat di bawah Obama berfokus pada pemulihan atau restorasi kepemimpinan Amerika Serikat 
di dunia. Hal ini tertulis dalam National Security Strategy 2010 :

"Our national security strategy is, therefore, focused on renewing American leadership so that we can more effectively advance our interests in the 21st century."(NSS 2010)

Lebih lanjut tidak hanya merestorasi kepemimpinan Amerika Serikat juga sadar bahwa terdapat potensi ancaman terhadap dominasinya di dunia melalui munculnya kekuatan-kekuatan baru di dunia. Untuk itu Amerika Serikat perlu untuk semakin terlibat pada kawasan-kawasan potensial. Seperti yang tertulis dalam National Security Strategy:

"We must focus American engagement on strengthening international institutions and galvanizing the collective action that can serve common interests such as combating violent extremism; stopping the spread of nuclear weapons and securing nuclear materials; achieving balanced and sustainable economic growth; and forging cooperative solutions to the threat of climate change, armed conflict, and pandemic disease.The starting point for that collective action will be our engagement with other countries."(NSS 2010)

Sejalan dengan kepentingan tersebut maka Amerika Serikat kemudian harus merespon terhadap potensi ancaman terhadap upaya untuk merestorasi kepemimpinan dan untuk semakin terlibat di kawasan, salah satu ancaman dalam konteks ini hadir dari semakin naiknya pengaruh Cina dalam sphere of influence Amerika Serikat yang ditunjukkan melalui tiga hal yaitu keterlibatan dalam organisasi kawasan, perluasan ekonomi kawasan, serta upaya pengurangan dan pengelolaan potensi ancaman di kawasan.

\section{Cina dan Keterlibatan dalam Organisasi Kawasan}

Secara umum Asia-Pasifik merupakan kawasan yang memiliki perkembangan signifikan dalam proliferasi organisasi dan perjanjian di wilayahnya. Meskipun tidak terinstitusi sekuat Uni Eropa namun secara kuantitas jumlah organisasi kawasan semakin meningkat dalam waktu yang relatif singkat pada era paska perang dingin. Pada kurun waktu tersebut Asia-Pasifik diwarnai oleh munculnya ASEAN +1 (ASEAN dan Cina), ASEAN +3 (ASEAN, Cina, Jepang dan Korea Selatan), ASEAN Regional Forum (ARF), ASEAN Vision Group, ASEAN Senior Official Meeting (SMO), Shanghai Cooperation Organization (SCO), Pacific Basin Economic Council, East Asian Summit, Asia Pacific Economic 
Cooperation, East Asia Latin America Cooperation, Council on Security Cooperation in the Asia Pacific serta Northeast Asia Security Cooperation Dialogue (Sambaugh 2003; Acharya 2014). Dalam seluruh forum ini Cina merupakan aktor yang terlibat aktif baik dalam perumusan maupun dalam dinamika kegiatannya. Namun partisipasi Cina yang paling signifikan dalam upaya konsolidasi kekuatan di kawasan terlihat dalam keterlibatan Cina dengan ASEAN dan SCO. Hal ini diungkapkan oleh Direktur Jenderal Asia Kementerian Luar Negeri Cina, Fu Ying:

"Taking ASEAN + 3 cooperation and SCO as two focal points, China will make pioneering efforts to set up regional cooperation and push for the establishment of a regional cooperation framework conforming to the characteristic of regional diversity."(Fu Ying 2003)

SCO merupakan organisasi kawasan yang didirikan pada Juni 2001 yang beranggotakan Cina, Kazakhstan, Kyrgzystan, Rusia, Tajikistan dan Uzbeskistan. Cina memainkan peran penting dalam penciptaan organisasi ini melalui penempatan sekretariat permanen SCO di Beijing, selain itu Cina juga merupakan donatur utama dalam organisasi ini (Sambaugh 2004). Secara umum SCO memiliki tugas utama untuk mengkoordinasikan kerjasama dalam melawan isu keamanan non tradisional utamanya terorisme. Namun pada tahun 2003, SCO berubah menjadi organisasi yang lebih luas dan komprehensif saat PM Wen Jiabao membawa proposal perdagangan bebas dan pengurangan hambatan non tarif kepada negara anggotanya. Oleh karena itu hingga sekarang SCO menjadi upaya Cina untuk mendekatkan diri dengan Rusia dan Asia Tengah dalam pemberantasan terorisme dan perwujudan perdagangan bebas.

Selain SCO, Cina juga terlibat dalam ASEAN, keterlibatan ini memiliki signifikansi yang lebih penting dalam upaya konsolidasi kekuatan Cina di kawasan Asia-Pasifik (Sambaugh 2004). Pada KTT Cina-ASEAN 2002 Cina melakukan langkah progresif kerjasama dengan ASEAN melalui empat perjanjian penting yaitu Declaration on Conduct (DOC) in South China Sea, Joint Declaration on Cooperation in the Field of Non-Traditional Security Issues, The Framework Agreement on Comprehensive Economic Cooperation (ASEAN-China FTA) dan Memorandon of Understanding on Agricultural Cooperation. Selain itu, pada tahun 2003 Cina secara resmi melakukan aksesi terhadap ASEAN Treaty of Amity and Cooperation. Aksesi ini merupakan yang pertama kali dilakukan oleh negara nonASEAN. Hal ini memiliki konsekuensi bahwa Cina harus bertindak dalam prinsip nonagresi dan nonintervensi di kawasan ASEAN. Di tahun 
yang sama Cina juga menandatangani Joint Declaration on Strategic Partnership for Peace and Prosperity. Di tahun 2004 PM Wen melakukan inisiatif untuk mengembangkan kerangka ASEAN-FTA di kawasan Asia Timur serta mendorong terbentuknya East Asian Community (Sambaugh 2004).

Dari berbagai macam kerjasama di atas yang memiliki signifikansi paling penting adalah pembentukan ASEAN-China FTA (ACFTA). Perjanjian ini menjadi solusi bagi permasalahan ekonomi dan ekspor antara kedua aktor. Hal ini tercermin dari meningkatnya total perdagangan ASEANCina dari \$45,6 Miliar di tahun 2002 menjadi \$78,2 Miliar di tahun 2003, puncaknya pada tahun 2005 mencapai \$113,3 Miliar (Sambaugh 2004). Selain itu jika ACFTA terimplementasi secara penuh tahun 2010 maka akan terwujud pasar dengan total populasi lebih dari 2 Miliar jiwa dengan total GDP mencapai \$3 Triliun.

Fakta di atas mencerminkan bahwa Cina secara langsung memberikan ancaman bagi pengaruh Amerika Serikat di kawasan Asia-Pasifik, utamanya pada kawasan yang tidak mendapatkan perhatian dalam era Clinton dan Bush. Pendirian SCO sebagai alternatif upaya peningkatan kerjasama ekonomi dan keamanan di Asia Tengah utamanya dalam isu terorisme serta peningkatan kerjasama dengan ASEAN membuat Amerika Serikat berpotensi kehilangan jangkauan pengaruhnya pada kedua kawasan tersebut.

\section{Cina dan Perluasan Hubungan Ekonomi Regional}

Perluasan ekonomi di kawasan Asia utamanya merupakan refleksi naiknya Cina. Berdasarkan data pemerintah, total perdagangan antara Cina dan Asia mencapai angka \$495 Miliar pada tahun 2003 meningkat 36,5\% dari tahun 2002. Selain itu, pada tahun 2004 total perdagangan juga meningkat signifikan pada angka $42 \%$. Pada periode yang sama perdagangan dengan negara kawasan juga meningkat, India 85\%, Jepang 27\%, Malaysia 35\%, Filipina $47 \%$, Korea Selatan 46\%, Rusia 32\%, Thailand 38\% dan Vietnam $58 \%$ (Sambaugh 2004). 
Tabel 3 Perdagangan Cina dengan Negara Tetangga

\begin{tabular}{lc}
\hline \multicolumn{2}{l}{ Table 1. China's Trade with Neighboring Countries, 2003} \\
\hline Country & Total Trade Volume (U.S.\$) \\
\hline Afghanistan & $27.00 \mathrm{mn}$. \\
Australia & $13.56 \mathrm{bn}$ \\
Bangladesh & $1.36 \mathrm{bn}$. \\
Democratic Republic of Korea & $1.02 \mathrm{bn}$. \\
India & $7.59 \mathrm{bn}$. \\
Indonesia & $10.20 \mathrm{bn}$. \\
Japan & $133.57 \mathrm{bn}$. \\
Kazakhstan & $3.28 \mathrm{bn}$. \\
Laos & $109.40 \mathrm{mn}$. \\
Malaysia & $20.12 \mathrm{bn}$. \\
Mongolia & $439.80 \mathrm{mn}$. \\
Myanmar & $1.07 \mathrm{bn}$. \\
Nepal & $127.30 \mathrm{mn}$. \\
New Zealand & $1.82 \mathrm{bn}$. \\
Pakistan & $2.42 \mathrm{bn}$. \\
Philippines & $9.40 \mathrm{bn}$. \\
Republic of Korea & $63.23 \mathrm{bn}$. \\
Russia & $15.70 \mathrm{bn}$. \\
Singapore & $19.30 \mathrm{bn}$. \\
Sri Lanka & $524.20 \mathrm{mn}$. \\
Tajikstan & $38.80 \mathrm{mn}$. \\
Thailand & $12.65 \mathrm{bn}$. \\
Vietnam & $4.63 \mathrm{bn}$. \\
\hline
\end{tabular}

SouncE: China's General Administration of Customs, Ministry of Foreign Affairs of the People's Republic of China, China's Foreign Affairs, 2004 (Beijing: World Affairs Press, 2004).

\section{(sumber: MOFA Cina 2004)}

Selain itu, Cina juga meningkatkan investasi di kawasan dengan membuka diri dan memberikan bantuan. Hal ini terlihat dari total 70\% FDI yang diterima Cina berasal dari negara-negara Asia. Cina juga mengirimkan FDI ke negara-negara Asia dengan total mencapai \$1,5 Miliar dari total $\$ 2,85$ Miliar FDI yang diberikan oleh Cina pada tahun 2003. Cina juga meningkatkan bantuan luar negeri misalkan dengan Vietnam yang mencapai \$150 juta, dengan Indonesia yang mencapai \$400 Juta, serta dengan Afghanistan yang mencapai $\$ 200$ juta.

Dari data ini dapat disimpulkan bahwa melalui perdagangan dan investasi Cina telah menggerakkan ekonomi Asia dan membantu banyak negara dalam bidang ekonomi untuk mengisi kekosongan peran Jepang yang sedang menurun ekonominya. Oleh karena itu dampak yang terjadi adalah bahwa akan muncul ketergantugnan terhadap keberlangsungan pertumbuhan ekonomi dan stabilitas ekonomi Cina bagi kawasan Asia. Hal ini tentu menjadi ancaman tersendiri bagi Amerika Serikat dikarenakan Jepang sebagai aliansi yang diharapkan mampu untuk menjaga pengaruh Amerika Serikat di Asia tergantikan oleh Cina yang semakin agresif. 


\section{Cina dan Peningkatan Postur Keamanan Kawasan}

Dalam konteks keamanan Cina melakukan pendekatan yang berbeda dalam upayanya menjaga stabilitas kawasan dan memproyeksikan kekuatannya. Pola yang diambil adalah melalui modernisasi angkatan bersenjata Cina, namun hal ini tidak dapat berlangsung cepat sehingga Cina meningkatkan postur keamanan kawasan dengan cara lain sembari menunggu modernisasi angkatan bersenjatanya berjalan. Cara ini dilakukan dalam dua metode, pertama Cina melakukan dialog keamanan secara bilateral dengan mitra di kawasan seperti Australia, India, Jepang, Kazakhstan, Kyrgystan, Mongolia, Pakistan, Rusia dan Thailand secara tahunan yang melibatkan pertemuan tingkat tinggi hingga pertukaran personil militer dan latihan bersama(Acharya 2014). Hal ini menjadi pencapaian penting dikarenakan Cina melakukan latihan bersama dan pertukaran militer termasuk dengan aktor-aktor strategis kawasan seperti India, Pakistan, Rusia hingga Vietnam dan Thailand. Selain itu Cina juga melakukan dialog melalui track 2 lewat China Institute for International Strategic Studies dan China Foundation for International Strategic Studies.

Kedua, Cina meningkatkan partisipasi dalam ASEAN Regional Forum (ARF). Partisipasi ini menjadi penting dikarenakan pemerintah Cina menjadikan ARF sebagai katalis bagi terwujudnya komunitas keamanan kawasan. Hal ini disampaikan oleh Presiden Hu Jintao:

"China will give full play to existing multilateral security
mechanisms and is ready to set up a security dialogue
mechanism with other Asian countries to actively promote
con ${ }^{a}$ dence-building cooperation in the military field"
(Acharya 2014)

Pada pertemuan ARF tahun 2003, Cina memperkenalkan draf konsep pertukaran militer regional sebagai bentuk kebijakan keamanan kawasan. Draf konsep ini mencakup isu-isu yang cukup sensitif bagi Cina seperti strategi militer dan doktrin pertahanan, revolution in military affairs (RMA), modernisasi pertahanan, peran militer kawasan dalam menghadapi ancaman non tradisional, konversi pertahanan serta hubungan sipil militer. Hal ini dilakukan Cina untuk menegaskan keseriusannya untuk menciptakan desain keamanan kawasan. Draf ini akhirnya disetujui pada pertemuan ARF tahun 2004 sebagai salah satu pencapaian terbaik ARF mengenai desain keamanan regional. Selain itu Cina juga mendorong terbentuknya East Asian Security Communities dari ARF (Sambaugh 2004; Odegaard 2007). 
Kedua Indikasi diatas dari meningkatknya kapabilitas keamanan Cina hingga semakin tingginya intensitas dialog dengan mitra negara dan kawasan menunjukkan bahwa Cina tengah bersiap untuk menjadi hegemoni kawasan menggantikan pola interaksi yang dibangun oleh Amerika Serikat melalui Hub and Spoke serta pakta pertahanan aliansi di kawasan Asia.

Berdasarkan keempat indikator ini maka pemerintahan Obama dalam masanya dihadapkan pada kenyataan meningkatnya pengaruh Cina di kawasan Asia-Pasifik. peningkatan ini dapat diterjemahkan sebagai ancaman terhadap pola interaksi yang dibangun oleh Amerika Serikat di kawasan Asia-pasifik. Kawasan Asia-Pasifik menjadi penting dalam ruang lingkup pengaruh Amerika Serikat di Abad 21 dikarenakan wilayah ini merupakan tempat bertemunya negara-negara berkembang dan negara-negara besar yang sedang naik sehingga kawasan ini berpotensi menciptakan jalan bagi perubahan konstelasi dunia. Oleh karena itu, secara spesifik kenaikan Cina dan signifikansi Asia-Pasifik harus direspon oleh pemerintahan Obama sebagai perhatian utama dalam melakukan tata kelola hegemoni Amerika Serikat di dunia.

\section{Alokasi Sumber Daya Amerika Serikat: Pivot to Asia}

Indikator terakhir dari adanya perubahan Grand Strategy Amerika Serikat pada periode kedua Obama terlihat dari adanya alokasi dan mobilisasi sumber daya baik militer, ekonomi hingga politik oleh Amerika Serikat di kawasan Asia-Pasifik. Hal ini setidaknya dapat terbagi menjadi beberapa kebijakan utama yang salah satunya adalah pengerahan sumber diplomasi untuk menciptakan kerangka perdagangan bebas baru melalui Trans-Pacific Partnership. Secara umum strategi ini merupakan kerangka besar dari kebijakan Pivot to Asia yang dicetuskan oleh Obama.

Strategi Pivot to Asia ini berkaitan dengan upaya pemerintahan Obama untuk melakukan penyeimbangan terhadap kebijakan luar negeri Amerika Serikat yang berat sebelah dalam prakteknya ketika War On Terror. Strategi ini ditujukan untuk memenuhi ekspektasi ekonomi dan reputasi domestik paska era Bush. Hal ini diperkuat dengan fakta bahwa kemunculan teknologi dan pola baru dalam aksi kontra terorisme berujung pada tewasnya Osama Bin Laden pada Mei 2011 (BBC 2016). Pada prakteknya fokus kontra terorisme tidak berhenti di era Obama namun dijalankan dengan cara yang lebih halus dan cerdas. Oleh karena 
itu secara umum strategi penyeimbangan di era Obama dapat lebih berfokus pada isu-isu yang lebih struktural terkait dominasi hegemoni Amerika Serikat secara keseluruhan (Singh 2012; Bentley \& Holland 2014; Brown 2015). Doktrin ini memiliki makna bahwa pemerintahan Amerika Serikat telah melakukan pergantian fokus dari perang berkepanjangan melawan teror menuju isu struktural terkait ekonomi dan perwujudan tatanan internasional dengan fokus utama berada di kawasan Asia-Pasifik.

Dalam dimensi militer, strategi Pivot to Asia berkaitan dengan pengalihan dan penempatan tentara Amerika Serikat di kawasan Asia-Pasifik dari kawasan lain. Hal ini menjadi fokus utama yang dinyatakan Obama pada tahun 2011:

\begin{abstract}
"As we consider the future of our armed forces, we've begun a review that will identify our most important strategic interests and guide our defense priorities and spending over the coming decade. So here is what this region must know. As we end today's wars, I have directed my national security team to make our presence and mission in the Asia Pacific a top priority. As a result, reductions in U.S. defense spending will not-I repeat, will not-come at the expense of the Asia Pacific." (Obama 2011)
\end{abstract}

Kebijakan ini kemudian dilakukan dalam tiga indikator utama yaitu distribusi pasukan yang semakin luas, adanya fleksibilitas penempatan pasukan serta peningkatan kapabilitas mitra kawasan. Peningkatan distribusi pasukan berkaitan dengan penempatan tentara dalam jumlah yang lebih besar dan merata di kawasan Asia Pasifik hal ini ditunjukkan dalam tabel 4 
Tabel 4 Penempatan Pasukan AS di Asia-Pasifik

Figure I. Map of the Asia-Pacific

Including Selected U.S. Troop Deployments and Plans

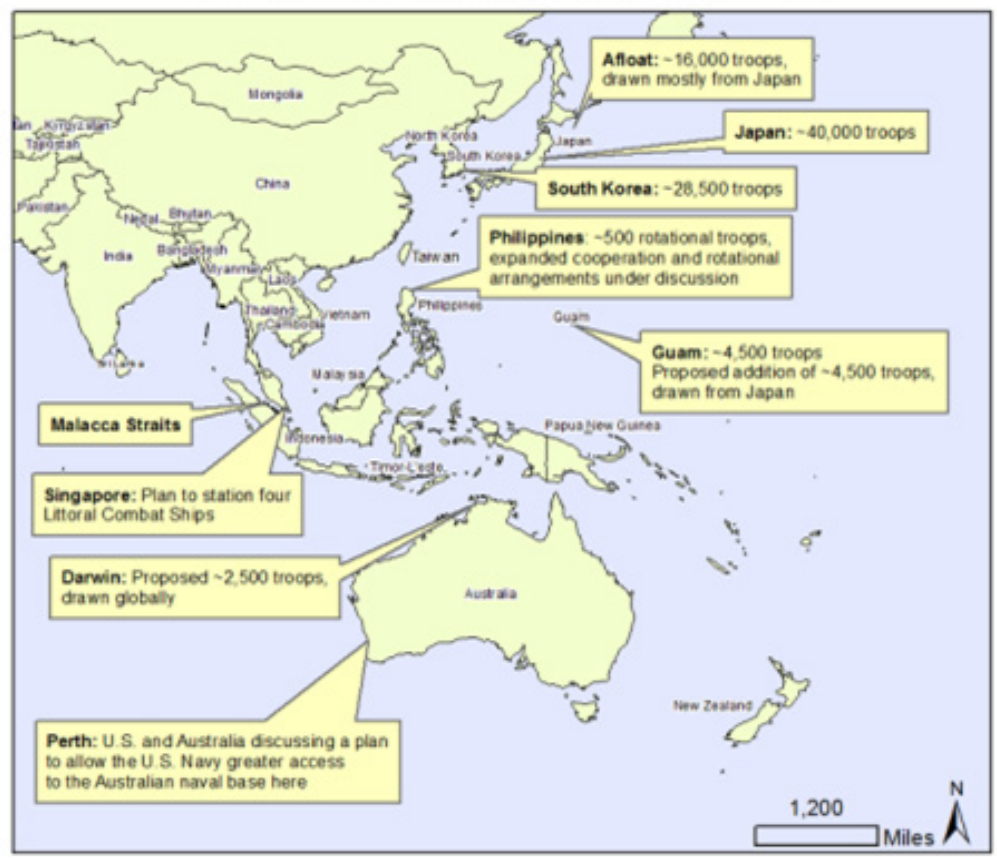

(sumber: Bentley \& Holland, 2014)

Secara spesifik peningkatan distribusi juga berkaitan dengan peningkatan kapabilitas pasukan di Australia melalui penambahan gugus tempur militer AS utamanya di kawasan Darwin dan Perth.Selain itu Amerika Serikat juga menambah jumlah littoral combat ships di Singapura dan melakukan diskusi lebih lanjut terkait dengan perjanjian pertahanan dengan Filipina (Bentley \& Holland 2014).

Dalam konteks diplomasi, strategi Pivot to Asia dilakukan dengan mengedepankan diplomasi multilateral dan peningkatan hubungan diplomatik dengan Cina. Hal ini juga ditunjukkan melalui meningkatnya kunjungan Menlu Hillary Clinton di kawasan Asia-Pasifik dibandingkan dengan para pendahulunya. 
Tabel 5 Perbandingan Kunjungan Menlu Clinton dengan Pendahulunya

\begin{tabular}{|c|c|c|c|c|c|c|c|c|}
\hline Region & $\begin{array}{l}\text { Clinton } \\
\text { Total, } \\
\text { First } \\
\text { Three } \\
\text { Years }\end{array}$ & $\begin{array}{l}\text { Clinton } \\
\text { First Three } \\
\text { Years, \% }\end{array}$ & $\begin{array}{c}\text { Rice } \\
\text { Total, } \\
\text { First } \\
\text { Three } \\
\text { Years }\end{array}$ & $\begin{array}{l}\text { Rice First } \\
\text { Three } \\
\text { Years, \% }\end{array}$ & $\begin{array}{l}\text { Powell } \\
\text { Total, } \\
\text { First } \\
\text { Three } \\
\text { Years }\end{array}$ & $\begin{array}{l}\text { Powell } \\
\text { First Three } \\
\text { Years, \% }\end{array}$ & $\begin{array}{l}\text { Albright } \\
\text { Total, } \\
\text { First } \\
\text { Three } \\
\text { Years }\end{array}$ & $\begin{array}{c}\text { Albright } \\
\text { First Three } \\
\text { Years, \% }\end{array}$ \\
\hline Africa & 13 & $7.1 \%$ & 4 & $2.2 \%$ & 14 & $9.0 \%$ & 14 & $7.1 \%$ \\
\hline East Asia \& Pacific & 36 & $19.7 \%$ & 18 & $9.8 \%$ & 21 & $13.5 \%$ & 26 & $13.2 \%$ \\
\hline Europe \& Eurasia & 54 & $29.5 \%$ & 64 & $35.0 \%$ & 48 & $31.0 \%$ & 100 & $50.8 \%$ \\
\hline Near East & 30 & $16.4 \%$ & 63 & $34.4 \%$ & 41 & $26.5 \%$ & 39 & $19.8 \%$ \\
\hline South \& Central Asia & 17 & $9.3 \%$ & 13 & $7.1 \%$ & 11 & $7.1 \%$ & 2 & $1.0 \%$ \\
\hline of which india & I & & 4 & & 1 & & 1 & \\
\hline Western Hemisphere & 33 & $18.0 \%$ & 21 & $11.5 \%$ & 20 & $12.9 \%$ & 16 & $8.1 \%$ \\
\hline Totals & 183 & $100.0 \%$ & 183 & $100.0 \%$ & 155 & $100.0 \%$ & 197 & $100.0 \%$ \\
\hline
\end{tabular}

(sumber: Congressional Research Service, 2012)

Diplomasi multilateral pada Pivot to Asia difokuskan pada keterlibatan Amerika Serikat secara lebih dalam di ASEAN Regional Forum yang merupakan pertemuan dialog keamanan kawasan beranggotakan 27 negara di kawasan. Serta dalam East Asia Summit yang merupakan pertemuan negara-negara ASEAN ditambah dengan mitra kawasan termasuk Cina dan Amerika Serikat (Manyin et.al 2012).

Sementara itu dalam bidang ekonomi secara spesifik pemerintahan Obama terlibat secara langsung dalam negosiasi Trans-Pacific Partnership yang dikemukakan oleh Obama :

"The United States will also be engaging with the TransPacific Partnership countries with the goal of shaping a regional agreement that will have broad-based membership and the high standards worthy of a 21st century trade agreement. "(Obama 2011)

Keterlibatan ini menunjukkan adanya perhatian lebih dalam kebijakan ekonomi dan pentingnya keterlibatan kawasan Amerika Serikat dalam upaya pengembalian legitimasi dan pengaruh Amerika Serikat di kawasan Asia-Pasifik. Keterlibatan dalam TPP ini menjadi penting dalam upaya untuk merespon terhadap ancaman yang telah ditimbulkan oleh naiknya Cina. Hal ini dikarenakan TPP secara umum merupakan perjanjian dagang yang diharapkan dapat meningkatkan kerjasama AS dan Asia-Pasifik serta secara tidak langsung menghindarkan dan atau mengurangi pengaruh Cina di kawasan (Elm 2012; Barfield 2016). 
Hal ini dilakukan Amerika Serikat dalam upaya mengatur jalannya agenda negosiasi melalui dua agenda utama yaitu pengaturan mekanisme aksesi serta pengaturan poin aturan dalam perjanjian. Kedua langkah ini merupakan bentuk perwujudan dari intensi Amerika Serikat untuk membuat desain perdagangan kawasan yang menguntungkan bagi Amerika Serikat dan sekutunya namun membuat Cina untuk kesulitan bergabung.

Mekanisme aksesi TPP pada dasarnya sangatlah terbuka, dikarenakan tujuan utama dari perjanjian dagang ini adalah untuk mengajak sebanyakbanyaknya negara Asia-Pasifik untuk bergabung (Elm 2012). Oleh karena itu salah satu fitur utama dari negosiasi TPP adalah adanya pasal aksesi terbuka yang memperbolehkan bergabungnya negara dalam negosiasi kapanpun dengan syarat mendapatkan persetujuan dari anggota dan memenuhi syarat-syarat yang telah diterapkan. Fitur ini juga nantinya dilibatkan dalam pasal TPP yang bertujuan untuk memperluas ruang lingkup dan cakupan perdagangan di kawasan Asia Pasifik. Pasal ini tidak menutup kemungkinan bergabungnya negara lain dalam perjanjian, namun pada implementasinya nanti dalam TPP negara yang tergabung harus bersedia menerapkan keseluruhan pasal dan memenuhi prasyarat tambahan yang seringkali didorong oleh Amerika Serikat dalam prakteknya sebelum bergabung (Elm 2012; Barfield 2016).

Aturan tersebut membuat kebijakan Pivot to Asia Amerika Serikat yang bertujuan untuk mengurangi pengaruh Cina menjadi menarik dikarenakan, Amerika Serikat tidak secara langsung menolak atau melakukan konfrontasi terhadap Cina namun yang dilakukan adalah Amerika Serikat menunjukkan bahwa kekuatan diplomasi dan ekonomi Amerika Serikat masih berkuasa di kawasan Pasifik melalui penciptaan perjanjian dagang ini. Selain itu Cina akan menjadi kesulitan untuk bergabung dengan TPP dikarenakan terdapat poin-poin perjanjian yang sangat jelas tidak akan mampu dipenuhi oleh Cina. Yaitu pada poin pengadaan pemerintah, perdagangan kompetitif, BUMN, Kekayaan intelektual, tenaga kerja dan lingkungan. Kesemua poin negosiasi yang dicetuskan oleh Amerika Serikat ini menjadi hambatan bagi kemajuan ekonomi Cina. Oleh karena itu TPP disebut sebagai perjanjian perdagangan bebas yang paling maju dikarenakan dalam poin negosiasinya sudah membahas isu-isu yang jarang dan bahkan tidak dibahas oleh perjanjian perdagangan konvensional. 


\section{Simpulan}

Dari penjelasan di atas dapat ditarik simpulan bahwa Obama pada periode keduanya menerapkan strategi selective engagement yang berfokus pada upaya peningkatan keterlibatan Amerika Serikat dalam kawasan-kawasan yang berpotensi mengancam kepentingan nasionalnya secara langsung. Hal ini terlihat dari kemunculan Cina dalam ruang lingkup pengaruh Amerika Serikat yang lantas menjadi ancaman serius bagi upaya restorasi kepemimpinan Amerika di dunia. Namun, naiknya Cina ternyata tidak lantas diabaikan Amerika Serikat seperti para pendahulunya yang berfokus pada War on terror. Obama justru meningkatkan keterlibatan Amerika Serikat di Asia-Pasifik guna melindungi upaya restorasi kekuatan Amerika Serikat di dunia. Upaya ini direalisasikan Obama melalui kebijakan Pivot to Asia yang berfokus untuk secara tidak langsung meningkatkan keterlibatan Amerika Serikat di kawasan. Kebijakan ini ditandai dengan tiga aspek penting yaitu reorganisasi militer Amerika Serikat ke AsiaPasifik, peningkatan hubungan diplomatik dengan negara-negara di AsiaPasifik, serta dengan menginisiasi negosiasi Trans-Pacific partnership yang bertujuan untuk membuat desain ekonomi regional guna merealisasikan tujuan restorasi kepemimpinan Amerika Serikat. Ketiga kebijakan ini tidak hanya dilakukan sebagai upaya perlindungan terhadap kepentingan nasional namun juga memiliki tujuan untuk menjaga agar pengaruh Cina tidak mengurangi pengaruh Amerika Serikat di kawasan. Oleh karena itu dapat dikatakan bahwa strategi Pivot to Asia merupakan representasi dari Grand Strategy selective engagement yang dilakukan oleh Obama. Namun, penulis menyadari bahwa argumentasi penulis masih merupakan argumen yang hanya berfokus pada level sistemik. Maka tidak tertutup kemungkinan untuk mengeksplorasi dimensi lain dari Grand Strategy seperti level domestik dan individu yang mungkin dapat menambah pengetahuan menyeluruh terhadap analisis Grand Strategy Amerika Serikat pada era Obama. 


\section{Referensi}

\section{Buku dan Artikel dalam Buku}

Barfield, C., 2016. Trans-Pacific Partnership and America's strategic role in Asia, dalam The Trans-Pacific Partnership and the Path To Free Trade in the Asia-Pacific, pp.30-48.

Bentley, M. and Holland, J. eds., 2013. Obama's Foreign Policy: Ending the War on Terror. Routledge.Brown, S., 2015. Faces of Power: Constancy and Change in United States Foreign Policy from Truman to Obama. Columbia University Press.

Lim, C.L., Elms, D.K. and Low, P.eds., 2012. The trans-pacific partnership: a quest for a twenty-first century trade agreement. Cambridge University Press.

Gardner, H., 2005. American Global Strategy and the'war on Terrorism'. Routledge.

Hayden, C., 2012. The rhetoric of soft power: Public diplomacy in global contexts. Lexington Books.Layne, C., 2007. The peace of illusions: American grand strategy from 1940 to the present. Cornell University Press.

Finkelstein, D.M., 2003. Modernizing China's Military: Progress, Problems, and Prospects. Berkeley: University of California Press

Singh, R., 2012. Barack Obama's post-American foreign policy: the limits of engagement. Bloomsbury Publishing.

Wittkopf, E.R., Jones, C.M. and Kegley Jr, C.W., 2008. American foreign policy: Pattern and process. Nelson Education.

\section{Jurnal dan Jurnal Daring}

Acharya, A., 2014. Power shift or paradigm shift? China's rise and Asia's emerging security order. International Studies Quarterly, 58(1), pp.158-173.Fu, Ying., 2003. China and Asia in a New Era. China: An International Journal, 1(02), pp.304-312.

Layne, C., 1998. Rethinking American grand strategy: Hegemony or balance of power in the twenty-first century?. World Policy Journal, 15(2), pp.8-28.

Layne, C., 2006. The unipolar illusion revisited: The coming end of the United States' unipolar moment. International security, 31(2), pp.741.

Leffler, M.P., 2004. Bush's foreign policy. Foreign Policy, pp.22-28. 
Odgaard, L., 2007. The balance of power in Asia-Pacific security: US-China policies on regional order. The Korean Journal of Defense Analysis, 19(1), pp.29-46.

Posen, B.R. and Ross, A.L., 1997. Competing visions for US grand strategy. International Security, 21(3), pp.5-53.

Rowland, R.C., 2010. The fierce urgency of now: Barack Obama and the 2008 presidential election. American Behavioral Scientist, 54(3), pp.203-221.

Obama, B., 2007. Renewing american leadership. Foreign Affairs, pp.216.

\section{Artikel Daring}

BBC, 2012. Osama Bin Laden's death: How it happened [Online] http://www.bbc.com/news/world-south-asia-13257330 [DIakses 5 Desember 2016]

CNN. 2009 "At U.N., Obama calls for new era in world relations [online]", http://edition.cnn.com/2009/POLITICS/o9/23/obama.un/index. html?eref=onion, [Diakses 10 Desember 2016]

Brzezinski, Z., 2010. "From hope to audacity: Appraising Obama's foreign policy". Foreign Affairs, pp.16-30.Drezner, D.W., 2011. "Does Obama have a grand strategy? Why we need doctrines in uncertain times". Foreign Affairs, pp.57-68.Hirsh, M., 2002. "Bush and the World". Foreign Affairs, pp.18-43.Rumsfeld, Donald. 2002. "DoD News Briefing" [online] http://archive.defense.gov/Transcripts/Transcript. aspx?TranscriptID=2636 [Diakses 15 Desember 2016]

Obama, Barrack. 2009 "Remarks by President Obama at Suntory Hall". Pidato pada 14 November 2009 [online] https://www.whitehouse. gov/the-press-office/remarks-president-barack-obama-suntory-hall [Diakses 1 Oktober 2016]

\section{Lain - Lain}

US Constitution Article 2 Section 2

Manyin et.al, "Pivot to the Pacific? The Obama Administration Rebalancing Toward Asia”, Congressional Research Service, 2012 